\title{
Approaches on the Vulnerability of Romania's Economy in Terms of Budget Deficit and Inflation in a Continuous Form
}

\author{
Monica Laura Zlati \\ sorici.monica@,usm.ro \\ Stefan cel Mare University, Suceava, Romania \\ Valentin Marian Antohi \\ valentin_antohi@yahoo.com \\ Romeo Victor Ionescu \\ ionescu_vromeo@yahoo.com \\ Dunarea de Jos University, Galati, Romania
}

\begin{abstract}
The current conjecture of Romania's economy is marked by profound changes in fiscal and economic policy, with inconsistent effects of economic strategies at micro and macro levels, with repercussions in the evolution of efficiency indicators of the Consolidated General Budget. The paper is focused on identifying the current vulnerabilities of the national economy by building an econometric model, starting to the Consolidated General Budget's revenues and expenditures evolution during 20142018. The research methods cover: literature review, database analysis, their consolidation and the conceptualization of an econometric fiscal model. The results of the analysis have diagnosed the stage of economic and financial pre-crisis in Romania.
\end{abstract}

Keywords: budget deficit, inflation, GDP, financial crisis, macroeconomics vulnerability.

JEL: G 01, H 69, P 44

\section{Introduction}

Starting to 2017, Romania faced to economic contraction which has manifested itself as an internal economic crisis in all sectors of activity. The main element which supported this evolution was the implementation of fiscal policy measures aimed at covering the budget deficit generated by the wage increase in the public sector. The frequency of legislative changes in public policy and the political instability have generated increased volatility in the medium and short term development strategy. The lack of vision of the Romanian legislative structures has deeply affected the market economy mechanism in our country. As a result, Romania has gone from a sustained growth during 2014-2016 to an uncertainty similar to an economic crisis, nowadays. The main affected sector was the social one, due to the decline in welfare as a result of rising prices of goods and services and lowering purchasing power. It was followed by the economic sector that has suffered declines in economic returns, reflected in the main economic and financial indicators' trend.

One of the vulnerabilities that have affected Romania's economy lately and which derives from the inconsistency of the applied economic policy measures is represented by inflation and public debt. These aspects were analysed by the dedicated literature using the intrastate cooperation relations to reduce economic vulnerabilities by capitalizing the competitive export benefits and increasing the foreign direct investment (Gnangnon, 2017; Gnangnon and Iyer, 2017). At the end of 2018 , Romania faced to a maximum level of inflation of $4.3 \%$ compared to the European average inflation of 1.5\%(European Commission, 2018). This represented a risk factor for the domestic demand for goods and services. Moreover, it diminished the private consumption and affected the economic performance of the companies.

In the same year, 2018 , the public debt increased to $3.3 \%$ of GDP, compared to $2.9 \%$ of GDP in the previous year. These evolution was supported by an increase in the wage bill in the public sector, especially in health and education. In 2019, the public deficit will maintain its 
growth (European Commission, 2018) and will achieve the maximum level in 2020 (4.7\% of GDP). These forecasts took into consideration the aligning of the remuneration of employees in the public system at European level by annual growth schemes.

The present research aims to highlight, on the basis of the structure of public expenditures and public revenues, the difference in the position of the Romanian economy relative to the EU economy by identifying the causes of vulnerability and building a more steps macroeconomic stabilization model for an average time horizon.

\section{Literature review}

The issue of budgetary austerity under the conditions of public deficit is treated by the theory of macroeconomic shocks, based on the forecasting analyses for the linearization of the evolution of the budget deficit by econometric modelling (Cherif and Hasanov, 2017; GomezGonzalez, 2019).

An element in the budget deficit recovery equation is the national fiscal policy, with the role of economic regulator.

Given the excessive use of the economic regulator by increasing the fiscal pressure, macroeconomic austerity is generated and has directly negatively impacts on the economic growth. In the economic recovery equation, the regulator should be seen in relation to the investment financing policy, the minimization of the impact of inflation and the strategy of protecting the national capital, through measures of economic revival (Reinhart and Sbrancia, 2011; Meinusch and Tillmann, 2016).

The Euro area represents a successful model in combining fiscal policy elements with limiting inflation expansion and the deflator of public debt. In recent years, through the mechanisms of economic cohesion in the EU, significant progresses have been mad.

As a result, the EU economic growth poles (Germany and France succeeded in improving their economic evolution by flattening the cycles of economic growth's sinusoids as a real duopoly. This is why some specialists (Jarociński and Maćkowiak, 2018) developed an extended equilibrium model for mitigating the effects of the public debt in the Euro area able to quantify the effects of the economic crisis and post crisis in the region.

Other authors address the problem of budget deficit in terms of getting closer to the poverty line and the trap of the dependence of national economies on transactions with neighbouring countries, quantifying disadvantaged economic flows through the waste of public reserves on imports of high added value goods and services that weaken national economies and grow the degree of poverty (Menuet, Minea and Villieu, 2018).

Theory deviation from Ricardian equivalence (Eusepi and Preston, 2018) addresses the inflections in the stability of goods and services prices as a factor in compromising monetary policy with transpositions in substitution chains of national consumption. Along with increasing financial know-how, inflationary slippages can be controlled by policy-makers by realistically assuming of the current economic uncertainties.

In order to build the interaction panel between tax rules and inflation, some researches (Combes et al., 2018) investigated the results of national fiscal performance for 20 years, identifying the coordinates of the financial policy mix for the potential benefits of macroeconomic reforms.

The current trends in the dedicated literature suggest that tax constraints can be discretionarily used if consumption taxation is optimized.

The balance between public revenues and expenditures reflected in GDP is the source of sustainable economic growth, given that any debt has associated additional costs that once matured reveal the economic growth (Del Negro, Giannoni and Schorfheide, 2015; Westerhout and Beetsma, 2019). 
3. Research methodology

The present research succeeded in assessing economic vulnerabilities induced by budget deficit and continuing inflation. As a result, an econometric model was built and developed. It is able to capture the trend of GDP in relation to public revenues or expenditures. It is estimated that the GDP trend quantifies the vulnerabilities if it is identified with the spatial coordinates of the evolution of expenditures. Conversely, if the GDP trend is identified with the revenues' trend, then we can say that the national economy presents elements of sustainable growth over an average time horizon.

The model was built on the following hypotheses:

H1 - during economic deflation, the general trend of the economy tends to grow; on the other hand, during economic inflation, the general trend of the economy tends to decrease, and public debt to grow;

$\mathrm{H} 2$ - the inconsistent evolution of the budgetary revenues manifests especially in the area of current revenues through the component of non-tax revenues. It is the result of the entropy of the fiscal system and its inertial evolution;

H3 - the expenditures' volatility does not respect the entropy rules, with the highest volatility being in the current expenditure segment. The most obvious volatility for Romania is the low absorption rate of European funds with related accessories due to the financial badmanagement.

The proposed model uses the corrected Heteroskedasticity method for the dependent variable (GDP) in relation to total public revenue redressers (TI), and total public expenditure (TE.).

The model was built using the dedicated software Gretl, 2018 version, and led to a multiplicative model equation:

$$
\begin{gathered}
{ }^{\wedge} \mathrm{GDP}=-2,73 * \mathrm{TI}+5,54 * \mathrm{TE} \\
(0,891) \quad(0,830) \\
\mathrm{n}=5, \mathrm{R} \text {-squared }=0,993 \\
\text { (standard errors in parentheses) }
\end{gathered}
$$

The data used for econometric modelling were obtained from the website of the Ministry of Finance (Ministerul Finantelor Publice, 2018), including where the executions of the consolidated general budget during 2014 - 2018 ( $n=5$ ), and have been consolidated through the Microsoft Office - Excel software.

Using the above trend equation, the econometric model reflects the fact that GDP dynamics is closer to the dynamics of the total public expenditures compared to the total public revenues dynamics during the analysed period. Under H1 Hypothesis, it reflects the economic vulnerability and inflationary trends of the national economy.

The obtained statistical values reflect the fact that the model is homogeneous, well determined, with a statistical representability degree of $99.3 \%$. The p-values of the residual variables have generated high significance graduates especially on the public spending regressor TE ( $\mathrm{p}$ value $<0.01$ ), while the total public revenue regressor- TI ( $\mathrm{p}$ value $<0.1)$. The statistical

\begin{tabular}{|c|c|c|c|c|c|}
\hline \multicolumn{6}{|c|}{ Dependent variable: GDP } \\
\hline & Coefficient & Std. Error & t-ratio & p-value & \\
\hline Total Revenue & -2.72691 & 0.890892 & -3.061 & 0.0550 & $*$ \\
\hline Total Expenditure & 5.53864 & 0.829598 & 6.676 & 0.0069 & *** \\
\hline & Statistics & ed on the w & ed data: & & \\
\hline
\end{tabular}
tests are presented below:

Model 5: Heteroskedasticity - corrected, using observation 2-6 $(\mathrm{n}=5)$ Dependent variable: GDP 
Sum of residuals squares

R-square unadjusted

$\mathrm{F}(2,3)$

Log-likelihood

Schwarz criterion
3.889769

0.992856

208.4655

$-6.466972$

16.15282
Standard regression error

Adjusted R-squared

P-value(F)

Akaike criterion

Hannan-Quinn
1.138679

0.990475

0.000604

16.93394

14.83748

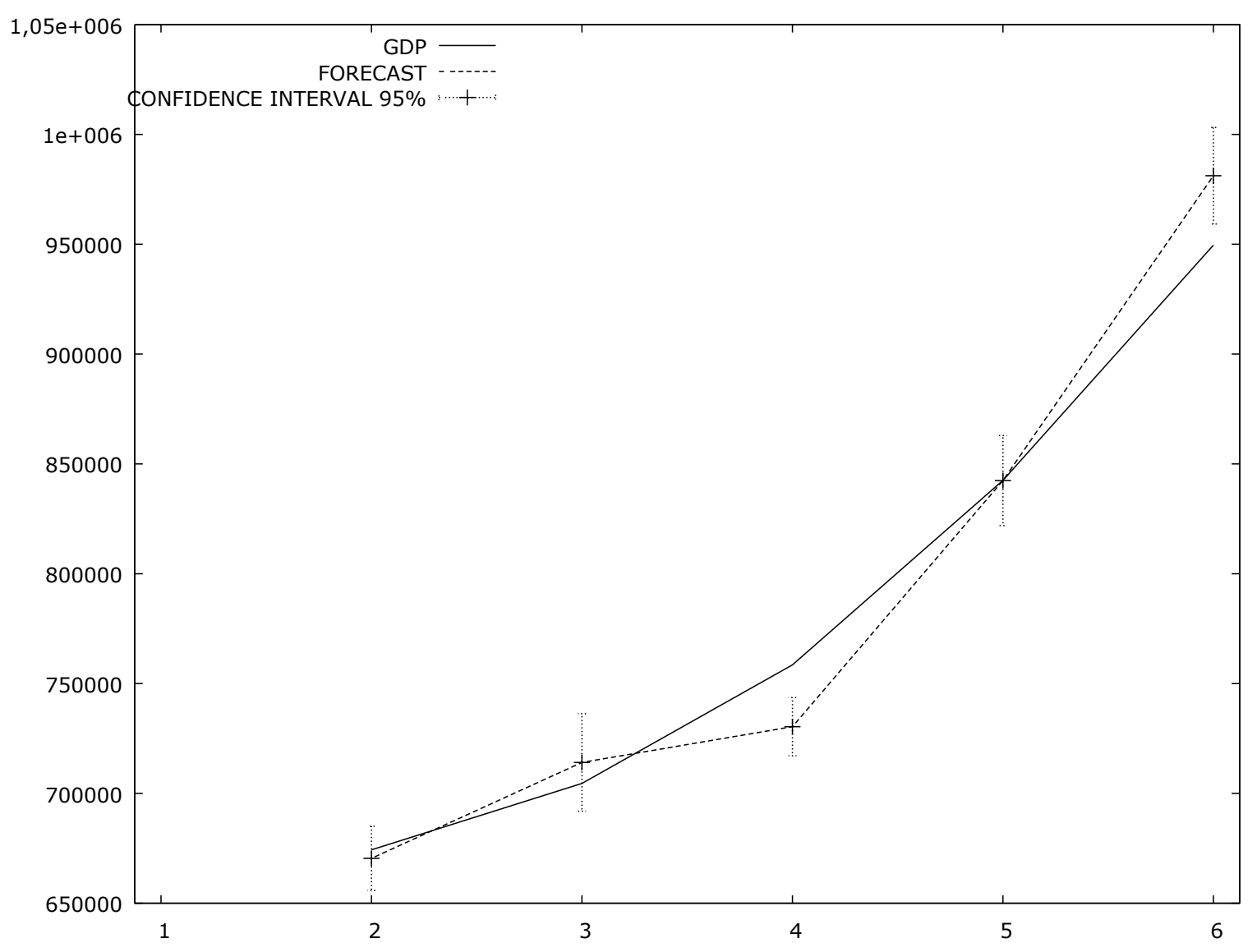

Figure 1 - The forecasted GDP distribution on the 95\% confidence interval Source: Authors' contribution

Figure 1 points out a relatively homogeneous evolution of the GDP axis, while the variations on the confidence interval do not exceed $+/-5$ trend units.

\section{Discussion}

During 2014-2018, Romania's GDP presented a positive trend which achieved 40\% on the whole period. The trend dynamic is characterised by the trend equation:

$$
y=-0.0039 x^{2}+0.0554 x+0.9486 .
$$

The mobile average analysis reflects a reduction in the multiplication trend from $4.48 \%$ in the first period (2014-2015) to 1.64\% in the last period (2017-2018) (see Table 1).

Table 1 - GDP's trend during 2014 - 2018

\begin{tabular}{|l|r|r|r|r|r|}
\hline \multicolumn{1}{|c|}{ Indicator/Year } & \multicolumn{1}{c|}{2014} & \multicolumn{1}{c|}{2015} & \multicolumn{1}{c|}{2016} & \multicolumn{1}{c|}{2017} & \multicolumn{1}{c|}{2018} \\
\hline GDP -mill. lei - & $674,300.00$ & $704,542.00$ & $758,500.00$ & $842,500.00$ & $949,600.00$ \\
\hline Mobile average (n/n-1) & $100.00 \%$ & $104.48 \%$ & $107.66 \%$ & $111.07 \%$ & $112.71 \%$ \\
\hline Multiplication trend & - & $4.48 \%$ & $3.17 \%$ & $3.42 \%$ & $1.64 \%$ \\
\hline
\end{tabular}

Source: Authors' contribution using official data published on the site: (Ministerul Finantelor Publice, 2018)

The total revenue in the general consolidated budget cover de 31\% of GDP and are characterised by the trend axis with the equation: 


$$
y=0.015 x^{2}-0.0524 x+1.0615
$$

The oscillation of the multiplication trend is asymptomatic with an inflection point in 2016, the global trend reduction being 50\% (Table 2).

Table 2 - Evolution of total income obtained from the Consolidated General Budget during 2014 - 2018

\begin{tabular}{|l|r|r|r|r|r|}
\hline \multicolumn{1}{|c|}{ Indicator/Year } & \multicolumn{1}{|c|}{2014} & \multicolumn{1}{|c|}{2015} & \multicolumn{1}{|c|}{2016} & \multicolumn{1}{c|}{2017} & \multicolumn{1}{c|}{2018} \\
\hline GDP -mill. lei - & $213,833.56$ & $233,554.29$ & $223,721.94$ & $251,819.70$ & $295,118.20$ \\
\hline Mobile average (n/n-1) & $100.00 \%$ & $109.22 \%$ & $95.79 \%$ & $112.56 \%$ & $117.19 \%$ \\
\hline Multiplication trend & & $9.22 \%$ & $-13.43 \%$ & $16.77 \%$ & $4.64 \%$ \\
\hline
\end{tabular}

Source: Authors' contribution using official data published on the site: (Ministerul Finantelor Publice, 2018)

The structure of total consolidated revenue consists of: Current Income; Capital Income; Donations; Amount received from EU; Amounts to be distributed; and Other amounts received from EU (Table 3).

Table 3 - Evolution of total income obtained from the Consolidated General Budget during $2014-2018$ on structural components

\begin{tabular}{|c|c|c|c|c|c|c|c|}
\hline Indicator/Year & 2014 & 2015 & 2016 & 2017 & 2018 & $\begin{array}{c}\text { Average } \\
(2014-2018)\end{array}$ & $\begin{array}{c}\text { Percentage of } \\
\text { representation } \\
(2014-2018)\end{array}$ \\
\hline TOTAL INCOME & $213,833.56$ & $233,554.29$ & $223,721.94$ & $251,819.70$ & $295,118.20$ & \multirow[t]{3}{*}{$243,609.54$} & \multirow[t]{3}{*}{$100.00 \%$} \\
\hline Mobile average $(\mathrm{n} / \mathrm{n}-1)$ & $100.00 \%$ & $109.22 \%$ & $95.79 \%$ & $112.56 \%$ & $117.19 \%$ & & \\
\hline Multiplication trend & & $9.22 \%$ & $-13.43 \%$ & $16.77 \%$ & $4.64 \%$ & & \\
\hline Current income & $199,774.41$ & $215,401.13$ & $215,618.81$ & $233,804.05$ & $267,738.60$ & \multirow[t]{3}{*}{$226,467.40$} & \multirow[t]{3}{*}{$92.96 \%$} \\
\hline Mobile average (n/n-1) & $100.00 \%$ & $107.82 \%$ & $100.10 \%$ & $108.43 \%$ & $114.51 \%$ & & \\
\hline Multiplication trend & & $7.82 \%$ & $-7.72 \%$ & $8.33 \%$ & $6.08 \%$ & & \\
\hline Capital income & $1,072.63$ & 918.21 & 769.39 & 830.35 & 849.40 & \multirow[t]{3}{*}{888.00} & \multirow[t]{3}{*}{$0.36 \%$} \\
\hline Mobile average (n/n-1) & $100.00 \%$ & $85.60 \%$ & $83.79 \%$ & $107.92 \%$ & $102.29 \%$ & & \\
\hline Multiplication trend & & $-14.40 \%$ & $-1.81 \%$ & $24.13 \%$ & $-5.63 \%$ & & \\
\hline Donations & 89.23 & 6.26 & 1.59 & 8.46 & 10.20 & \multirow[t]{3}{*}{23.15} & \multirow[t]{3}{*}{$0.01 \%$} \\
\hline Mobile average $(\mathrm{n} / \mathrm{n}-1)$ & $100.00 \%$ & $7.02 \%$ & $25.37 \%$ & $532.49 \%$ & $120.52 \%$ & & \\
\hline Multiplication trend & & $-92.98 \%$ & $18.35 \%$ & $507.12 \%$ & $-411.96 \%$ & & \\
\hline $\begin{array}{l}\text { Amount received } \\
\text { from EU }\end{array}$ & $11,099.67$ & $16,978.21$ & 949.89 & 276.55 & 247.00 & \multirow[t]{3}{*}{$5,910.26$} & \multirow[t]{3}{*}{$2.43 \%$} \\
\hline Mobile average (n/n-1) & $100.00 \%$ & $152.96 \%$ & $5.59 \%$ & $29.11 \%$ & $89.31 \%$ & & \\
\hline Multiplication trend & & $52.96 \%$ & $-147.37 \%$ & $23.52 \%$ & $60.20 \%$ & & \\
\hline $\begin{array}{l}\text { Amounts to be } \\
\text { distributed }\end{array}$ & 272.72 & -28.77 & 472.68 & 29.14 & -578.70 & \multirow[t]{3}{*}{33.41} & \multirow[t]{3}{*}{$0.01 \%$} \\
\hline Mobile average $(\mathrm{n} / \mathrm{n}-1)$ & $100.00 \%$ & $-10.55 \%$ & $-1642.90 \%$ & $6.16 \%$ & $-1986.00 \%$ & & \\
\hline Multiplication trend & & $-110.55 \%$ & $-1632.35 \%$ & $1649.07 \%$ & $-1992.16 \%$ & & \\
\hline $\begin{array}{l}\text { Other amounts } \\
\text { received from EU } *\end{array}$ & $1,524.89$ & -139.26 & 0.00 & -136.69 & $3,870.20$ & \multirow[t]{3}{*}{$1,023.83$} & \multirow[t]{3}{*}{$0.42 \%$} \\
\hline Mobile average (n/n-1) & $100.00 \%$ & $-9.13 \%$ & $0.00 \%$ & $-100.00 \%$ & $-2831.33 \%$ & & \\
\hline Multiplication trend & & $-109.13 \%$ & $9.13 \%$ & $-100.00 \%$ & $-2731.33 \%$ & & \\
\hline $\begin{array}{l}\text { Amounts received } \\
\text { from the EU / other } \\
\text { donors on account of } \\
\text { payments made and } \\
\text { pre-financing for } \\
2014-2020 \text { financial }\end{array}$ & & 418.50 & $5,909.58$ & $17,007.84$ & $22,981.50$ & $9,263.48$ & $3.80 \%$ \\
\hline
\end{tabular}


"Dunarea de Jos" University of Galati, Romania - Faculty of Economics and Business Administration

\begin{tabular}{|c|c|c|c|c|c|c|c|}
\hline Indicator/Year & 2014 & 2015 & 2016 & 2017 & 2018 & $\begin{array}{c}\text { Average } \\
(2014-2018)\end{array}$ & $\begin{array}{c}\text { Percentage of } \\
\text { representation } \\
\text { (2014-2018) }\end{array}$ \\
\hline \multicolumn{8}{|l|}{ framework } \\
\hline Mobile average (n/n-1) & $100.00 \%$ & $100.00 \%$ & $1412.08 \%$ & $287.80 \%$ & $135.12 \%$ & & \\
\hline Multiplication trend & & $0.00 \%$ & $1312.08 \%$ & $-1124.28 \%$ & $-152.68 \%$ & & \\
\hline
\end{tabular}

Source: Authors' contribution using official data published on the site: (Ministerul Finantelor Publice, 2018)

According to data in Table 3, the inflection point of 2016 related to the level of the total consolidated budget revenue is propagated by components, excepting the last two categories: Other amounts received from EU and Amounts received from the EU / other donors on account of payments made and pre-financing for 2014-2020 financial framework. Another pole of inflection manifested at the level of the revenues' components obtained from the Consolidated General Budget represents the year 2018, which records decelerations on the multiplication trend for all components, excepting Current income. Current income is able to redress revenue earned from the Consolidated General Budget as a multiplication trend through their fiscal function and impact on total revenues.

The fiscal policy applied for the immediate increase in current revenues has moved the moment of inflection to 2019. The continuous inflation will support the economic decreasing in Romania starting to the end of 2019 and the beginning of 2020. This development will also have a significant impact on GDP, which is on a regressive multiplication trend, the trend equation having a negative coefficient on the regression variable $\mathrm{x}^{2}$.

The cumulative effect of the EU contribution under financing programmes achieves $6.65 \%$ from the Total income from the Consolidated General Budget. The evolution of the multiplication trend leads to the inflection points in 2016 and 2018 (Table 4)

Table4 - Evolution of total income obtained from the Consolidated General Budget during 2014 - 2018 on Amounts received from the EU

\begin{tabular}{|c|c|c|c|c|c|c|c|}
\hline Indicator/Year & 2014 & 2015 & 2016 & 2017 & 2018 & $\begin{array}{c}\text { Average } \\
(2014-2018)\end{array}$ & $\begin{array}{l}\text { Percentage of } \\
\text { representation } \\
(2014-2018)\end{array}$ \\
\hline $\begin{array}{l}\text { Amounts received from the } \\
\text { EU / other donors on account } \\
\text { of payments made and pre- } \\
\text { financing }+ \\
\text { Other amounts received from } \\
\text { the EU for operational } \\
\text { programs financed under the } \\
\text { convergence objective }+ \\
\text { Amounts received from the } \\
\text { EU / other donors on account } \\
\text { of payments made and pre- } \\
\text { financing for 2014-2020 } \\
\text { financial framework }\end{array}$ & $12,624.57$ & $17,257.45$ & $6,859.46$ & $17,147.70$ & $27,098.70$ & \multirow[t]{3}{*}{$16,197.58$} & \multirow[t]{3}{*}{$6.65 \%$} \\
\hline Mobile average (n/n-1) & $100.00 \%$ & $100.00 \%$ & $39.75 \%$ & $249.99 \%$ & $158.03 \%$ & & \\
\hline Multiplication trend & & $0.00 \%$ & $-60.25 \%$ & $210.24 \%$ & $-91.95 \%$ & & \\
\hline
\end{tabular}

Source: Authors' contribution using official data published on the site: (Ministerul Finantelor Publice, 2018) 
Total expenditures reflected in the consolidated general budget account cover $33 \%$ of GDP, comparing to the share of total revenue of $31 \%$ of GDP, and are characterised by the trend axis with the equation: $\mathrm{y}=0.0095 \mathrm{x}^{2}-0.0171 \mathrm{x}+1.0226$.

The oscillation of the multiplication trend is asymptomatic with an inflection point in 2016. The global trend reduction is $35 \%$, compared to the total revenue of $50 \%$, with a favourable trend towards spending leading to a sustained budget deficit (Table 5).

Table 5 - Evolution of Total Expenditures to the Consolidated General Budget during 2014 -

\begin{tabular}{|l|c|c|c|c|c|}
\hline \multicolumn{1}{|c|}{ Indicator/Year } & 2014 & 2015 & 2016 & 2017 & 2018 \\
\hline $\begin{array}{l}\text { Total Expenditures - } \\
\text { mill. lei - }\end{array}$ & $226,326.79$ & $243,915.54$ & $242,016.28$ & $276,080.36$ & $322,454.50$ \\
\hline Mobile average (n/n-1) & $100.00 \%$ & $107.77 \%$ & $99.22 \%$ & $114.08 \%$ & $116.80 \%$ \\
\hline Multiplication trend & & $7.77 \%$ & $-8.55 \%$ & $14.85 \%$ & $2.72 \%$ \\
\hline
\end{tabular}

Source: Authors' contribution using official data published on the site: (Ministerul Finantelor Publice, 2018)

Total Expenditures to the Consolidated General Budget are divided in components, as the following: Current Expenditures (92.92\% of Total Expenditures), Capital Expenditures $(7.46 \%)$ and Payments made in previous years and recovered in the current year $(-0.38 \%)$. The inflexion point in 2016 is also spreading through components, with a bad management on Payments made in advance, which fail to be recovered in the current year in any of the analysed periods (Table 6).

Table 6 - Evolution of total expenditures obtained from the Consolidated General Budget during 2014-2018 on structural components

\begin{tabular}{|c|c|c|c|c|c|c|c|}
\hline Indicator/Year & 2014 & 2015 & 2016 & 2017 & 2018 & $\begin{array}{c}\text { Average } \\
(2014-2018)\end{array}$ & \begin{tabular}{|c|} 
Percentage of \\
representation \\
$(2014-2018)$
\end{tabular} \\
\hline $\begin{array}{l}\text { TOTAL } \\
\text { EXPENDITURES }\end{array}$ & $226,326.79$ & $243,915.54$ & $242,016.28$ & $276,080.36$ & $322,454.50$ & \multirow[t]{3}{*}{$262,158.69$} & \multirow[t]{3}{*}{$100.00 \%$} \\
\hline Mobile average (n/n-1) & $100.00 \%$ & $107.77 \%$ & $99.22 \%$ & $114.08 \%$ & $116.80 \%$ & & \\
\hline Multiplication trend & & $7.77 \%$ & $-8.55 \%$ & $14.85 \%$ & $2.72 \%$ & & \\
\hline Current expenditures & $210,135.93$ & $226,688.07$ & $223,001.24$ & $257,735.32$ & $300,392.10$ & \multirow[t]{3}{*}{$243,590.53$} & \multirow[t]{3}{*}{$92.92 \%$} \\
\hline Mobile average (n/n-1) & $100.00 \%$ & $107.88 \%$ & $98.37 \%$ & $115.58 \%$ & $116.55 \%$ & & \\
\hline Multiplication trend & & $7.88 \%$ & $-9.50 \%$ & $17.20 \%$ & $0.97 \%$ & & \\
\hline Capital expenditures & $17,140.06$ & $18,263.37$ & $19,015.03$ & $19,556.63$ & $23,861.10$ & \multirow[t]{3}{*}{$19,567.24$} & \multirow[t]{3}{*}{$7.46 \%$} \\
\hline Mobile average (n/n-1) & $100.00 \%$ & $106.55 \%$ & $104.12 \%$ & $102.85 \%$ & $122.01 \%$ & & \\
\hline Multiplication trend & & $6.55 \%$ & $-2.44 \%$ & $-1.27 \%$ & $19.16 \%$ & & \\
\hline $\begin{array}{l}\text { Payments made in } \\
\text { advance and } \\
\text { recovered in the } \\
\text { current year }\end{array}$ & -949.21 & $-1,035.90$ & 0.00 & $-1,211.60$ & $-1,798.80$ & \multirow[t]{3}{*}{-999.10} & \multirow[t]{3}{*}{$-0.38 \%$} \\
\hline Mobile average (n/n-1) & $100.00 \%$ & $-109.13 \%$ & $0.00 \%$ & $-100.00 \%$ & $-148.46 \%$ & & \\
\hline Multiplication trend & & $-209.13 \%$ & $109.13 \%$ & $-100.00 \%$ & $-48.46 \%$ & & \\
\hline
\end{tabular}

Source: Authors' contribution using official data published on the site: (Ministerul Finantelor Publice, 2018)

The general evolution of GDP trends, total revenue ratios and total expenditures in the Consolidated General Budget is shown in Figure 2. 


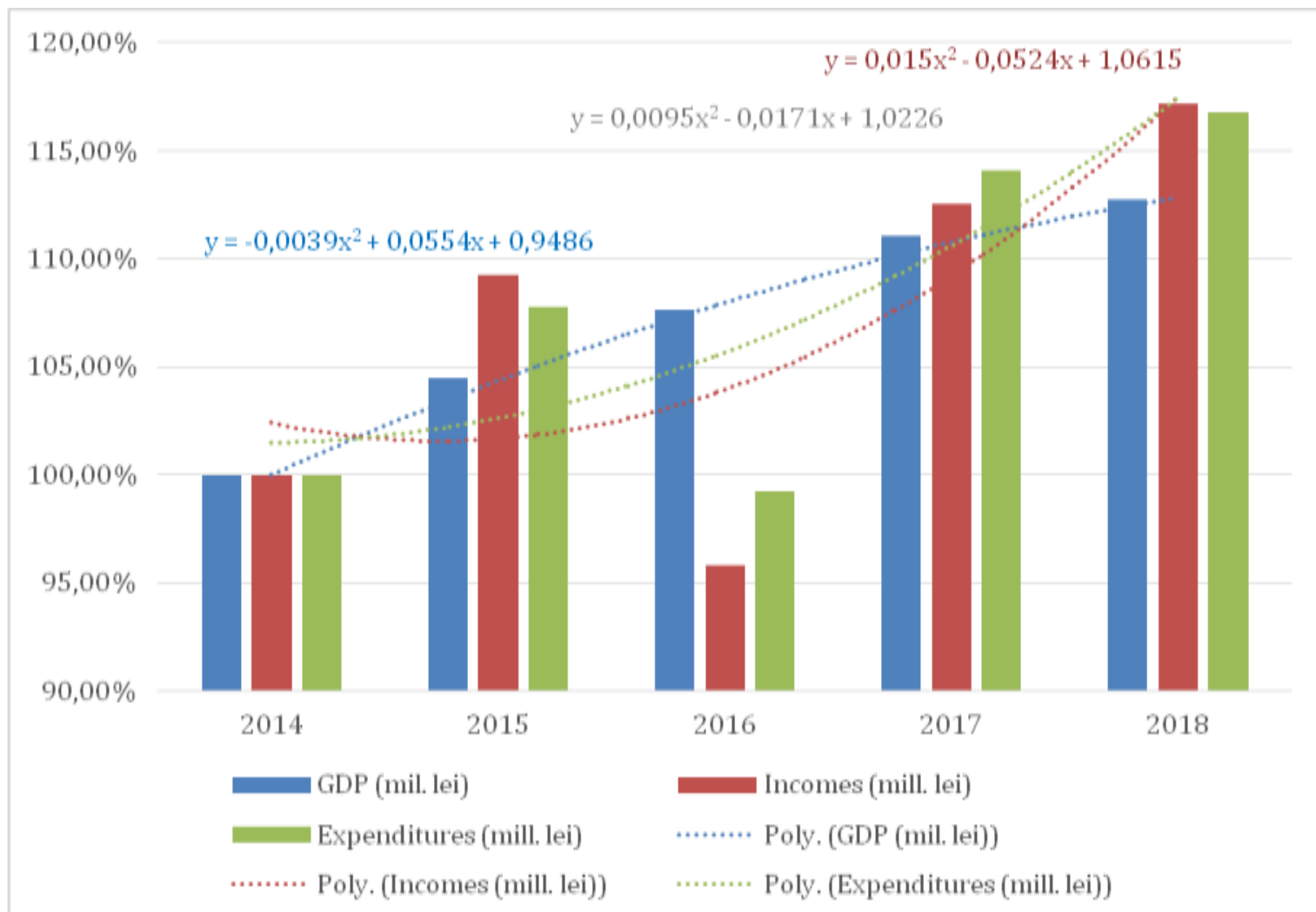

Figure 2 - The evolution trend of the general indicators of the General Consolidated Budget in relation to the GDP trend during 2014 - 2018

Source: Authors' contribution

The analysis presented in Figure 2 shows the differences in the trend evolution of the three indicators with inflection point in 2016 and the tendency to rectify the trend towards the end of the fiscal income period, which strengthens the total revenues of the General Consolidated Budget, over the evolution trend of the total expenditures at a level which fails to rebalance the overall indicator position in 2015. This evolution creates the premises for the causal explanation of the budget deficit registered each year of the analysed period as in Table 7.

Table 7 - Evolution of the budget deficit during 2014 - 2018 and its multiplication trend

\begin{tabular}{|c|c|c|c|c|c|c|c|}
\hline Indicator/Year & 2014 & 2015 & 2016 & 2017 & 2018 & $\begin{array}{c}\text { Average } \\
(2014-2018)\end{array}$ & $\begin{array}{c}\text { Percentage } \\
\text { of } \\
\text { represent- } \\
\text { tation } \\
(2014-2018)\end{array}$ \\
\hline $\begin{array}{c}\text { SURPLUS(+) / } \\
\text { DEFICIT(-) }\end{array}$ & $-12,493.22$ & $-10,361.26$ & $-18,294.34$ & $-24,260.66$ & $-27,336.30$ & \multirow{3}{*}{$-18,549.16$} & \multirow{3}{*}{$-7.08 \%$} \\
\hline Mobile average (n/n-1) & $100.00 \%$ & $17.06 \%$ & $-176.56 \%$ & $-132.61 \%$ & $-112.68 \%$ & & \\
\hline Multiplication trend & & $-82.94 \%$ & $-193.63 \%$ & $43.95 \%$ & $19.94 \%$ & & \\
\hline
\end{tabular}

Source: Authors' contribution using official data published on the site: (Ministerul Finantelor Publice, 2018)

The data in the above table (graphically transposed) reveals a downward trend distribution on the axis, characterised by the equation:

$$
y=-603.46 x^{2}-737.79 x-9697.7
$$

The distribution over the last analysed period (years 2017 - 2018) is above the general average of the budget deficit evolution, which anticipates a beginning of the economic crisis in Romania (Figure 3). 


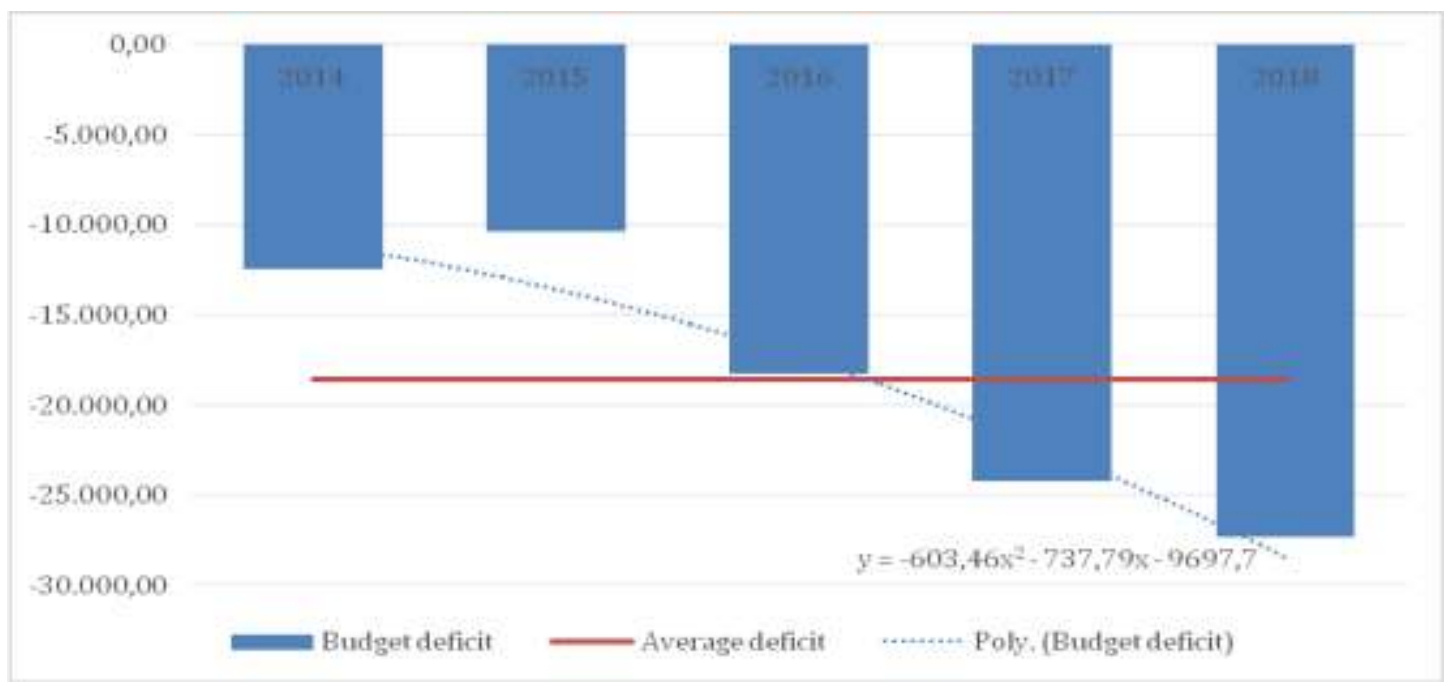

Figure 3 - The budget deficit trend in Romania during 2014 - 2018 Source: Authors' contribution

The above financial analysis confirms the results of the proposed econometric model and the study hypotheses as follows:

H1 - during the economic deflation, the general trend of the economy tends to grow; during the economic inflation, the general trend of the economy tends to decrease and the public debt to rise; under the trend equation, the econometric model reflects the fact that GDP dynamics is closer to the total public expenditures dynamics during the analysed period compared to the total public revenues dynamics. In light of the $\mathrm{H} 1$ hypothesis, this reflects the economic vulnerability and inflationary tendencies of the national economy;

$\mathrm{H} 2$ - the inconsistent evolution of the budgetary revenues manifests especially in the area of current revenues through the component of the non-fiscal revenues due to the entropy of the fiscal system and its evolutionary inertia; current revenues have a share of representation in total consolidated revenues of $92.96 \%$, which implies a movement of the total revenue trend in relation to direct dependence on current income. As explained above, the current revenue surplus on the basis of fiscal policy is able to flatten disparities to less significant components, including components of EU funding. The current revenue is mainly based on tax revenues, social contributions and non-tax revenues. The tax component is in a directly proportional relationship to the fiscal policy and objectives and to the national interest. Non-fiscal income has a higher degree of entropy freedom, knowing trend fluctuations on asymptotic curves with double or triple amplitudes towards tax revenue. They are expected to respect the general income and economic downturn, and the degree of fluctuation freedom is not harmonized with fiscal policy elements. The inflexion point of non-tax revenue is in 2016, when the multiplier trend experienced a $21 \%$ reduction compared to a $13 \%$ reduction in total revenue or $12 \%$ in tax revenue.

H3 - the volatility of expenditure does not respect the entropy rules, and the highest volatility is in the current expenditure segment. The financial bad-management in Romania points out as the most obvious volatility the low degree of abstraction of European funds with related accessories. This hypothesis was demonstrated by the obtained results from the application of the proposed econometric model and by the economic - financial analysis previously presented in the Discussions section.

\section{Conclusion}

Through the presented study, the authors demonstrated that Romania's economy is in the pre-crisis period, with macroeconomic vulnerabilities manifested by continuous inflation (EU maximum during 2 consecutive years) and evolutionary trends of the consolidated general government revenues / expenditures. The steady accumulation of budget deficits, corroborated 
with the downward trend of this indicator, marks a second major vulnerability of the national economic system, which fails to capitalize the GDP growth and to absorb the European funds, and creates premises for economic instability and financial instability. The proposed econometric model captures all these aspects and represents a rapid diagnosis element of economic pre-crisis and can be generalized to any national economy.

\section{References}

Cherif, R. and Hasanov, F. (2017) Public debt dynamics: the effects of austerity, inflation, and growth shocks', Empirical Economics. Springer Berlin Heidelberg. doi: 10.1007/s00181-017-1260-3.

Combes, J.-L. et al. (2018) 'Inflation Targeting, Fiscal Rules and the Policy Mix: Cross-effects and Interactions', The Economic Journal, 128(615), pp. 2755-2784. doi: 10.1111/ecoj.12538.

European Commission (2018) European Economic Forecast Autumn 2018. Autumn 201. Luxembourg: European Economy Institutional Papers. doi: 10.2765/020511.

Eusepi, S. and Preston, B. (2018) Fiscal Foundations of Inflation: Imperfect Knowledge', American Economic Review, 108(9), pp. 2551-2589. doi: 10.1257/aer.20131461.

Gnangnon, S. K. (2017) 'Structural economic vulnerability, openness and bilateral development aid flows', Economic Analysis and Policy, 53, pp. 77-95. doi: https:// doi.org/10.1016/j.eap.2016.12.001.

Gnangnon, S. K. and Iyer, H. (2017) 'Structural Economic Vulnerability, Trade Policy and FDI Inflows', Journal of International Commerce, Economics and Policy, 08(01), p. 1750005. doi: 10.1142/S1793993317500053.

Gomez-Gonzalez, P. (2019) 'Inflation-linked public debt in emerging economies', Journal of International Money and Finance, 93, pp. 313-334. doi: https:/ / doi.org/10.1016/j.jimonfin.2019.02.008.

Jarocinski, M. and Maćkowiak, B. (2018) 'Monetary-fiscal interactions and the euro area's malaise', Journal of International Economics, 112, pp. 251-266. doi: https:// doi.org/10.1016/j.jinteco.2017.12.006.

Meinusch, A. and Tillmann, P. (2016) 'The macroeconomic impact of unconventional monetary policy shocks', Journal of Macroeconomics, 47, pp. 58-67. doi: https://doi.org/10.1016/j.jmacro.2015.11.002.

Menuet, M., Minea, A. and Villieu, P. (2018) Deficit, monetization, and economic growth: a case for multiplicity and indeterminacy', Economic Theory, 65(4), pp. 819-853. Available at: bttps:/ / econpapers.repec.org/RePEc:spr:joecth:v:65:y:2018:i:4:d:10.1007_s00199-017-1040-5.

Ministerul Finantelor Publice (2018) Buletin MFP, Executii bugetare. Available at: bttp:/ / wnw.mfinante.gov.ro/pagina.btml?pagina=buletine categoriebunuri=executie-bugetara, rapoartetrimestriale, rapoarte-semestriale, rapoarte-anuale, arieratele-bugetului-general-consolidat (Accessed: 3 May 2019). Del Negro, M., Giannoni, M. P. and Schorfheide, F. (2015) 'Inflation in the Great Recession and New Keynesian Models', American Economic Journal: Macroeconomics, 7(1), pp. 168-196. doi: $10.1257 /$ mac.20140097.

Reinhart, C. M. and Sbrancia, M. B. (2011) The Liquidation of Government Debt. doi: 10.3386/w16893. Westerbout, E. and Beetsma, R. (2019) 'A comparison of nominal and indexed debt under fiscal constraints', Journal of International Money and Finance, 91, pp. 177-194. doi: bttps:// doi.org/10.1016/j.jimonfin.2018.12.006. 